\title{
Krill: a potential vector for domoic acid in marine food webs
}

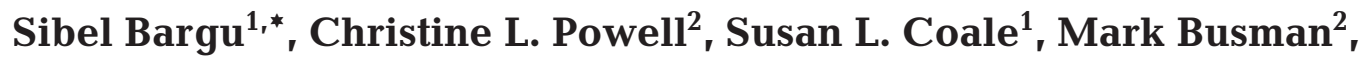 \\ Gregory J. Doucette ${ }^{2}$, Mary W. Silver ${ }^{1}$ \\ ${ }^{1}$ Department of Ocean Sciences, University of California at Santa Cruz, 1156 High Street, Santa Cruz, California 95064, USA \\ ${ }^{2}$ Marine Biotoxins Program, NOAA/NOS Center for Coastal Environmental Health \& Biomolecular Research, \\ 219 Fort Johnson Road, Charleston, South Carolina 29412, USA
}

\begin{abstract}
Over the past decade, blooms of the domoic acid (DA) producing diatom Pseudonitzschia have been responsible for numerous deaths of marine mammals and birds in Monterey Bay, California. Euphausiids (krill) are important members of the local zooplankton grazer community and comprise the primary diet of squid, baleen whales, and many seabirds. Krill are thus a key potential vector for the transfer of DA to higher trophic level organisms in Monterey Bay. A better understanding of the quantitative trophic interactions and body burden of DA in krill is required to predict whether they can act as an effective vector for this neurotoxin. Here we report results of toxin analyses and gut content examinations of krill Euphausia pacifica collected from Monterey Bay in 2000. Corresponding counts of toxic Pseudo-nitzschia species in the water and their cellular DA concentrations were also obtained at the collection sites. Toxin analysis by receptor binding assay demonstrated that DA in krill tissue varied between 0.1 to $44 \mu \mathrm{g}$ DA equiv. $\mathrm{g}^{-1}$ tissue (confirmed by tandem mass spectrometry), with levels corresponding to the abundance of toxic Pseudo-nitzschia species present in the water. The occurrence of Pseudo-nitzschia australis frustules in the digestive tract of E. pacifica verified that a toxic species of this diatom was an important part of their diet and thus implicated this phytoplankter as the source of DA. These findings provide compelling evidence for the role of krill as a potential transfer agent of the phycotoxin DA to higher trophic levels in marine food web.
\end{abstract}

KEY WORDS: Krill · Pseudo-nitzschia $\cdot$ Domoic acid $\cdot$ Harmful algal blooms $\cdot$ Toxic algae $\cdot$ Trophic transfer $\cdot$ Food webs

Resale or republication not permitted without written consent of the publisher

\section{INTRODUCTION}

Blooms of toxic phytoplankton are becoming more frequent and better documented in the world's oceans (Smayda 1989, Hallegraeff 1993, Van Dolah 2000). Although there is great concern about the effects of phycotoxins on higher organisms, including humans, marine mammals and birds, the links between toxic phytoplankton and these organisms are still not clear. The direct and rapid transfer of these toxins to the highest levels of the food chain requires herbivores that consume the toxic species. Therefore, identification of herbivorous vectors that can transfer phycotox-

\footnotetext{
*E-mail: sibelbargu@hotmail.com
}

ins to higher trophic levels becomes essential to understanding the fate of the toxins in marine ecosystems.

Monterey Bay, California, has been a region impacted by toxic phytoplankton populations over the last decade (Walz et al. 1994, Fryxell et al. 1997, Scholin et al. 2000). As is typical of many productive upwelling ecosystems, food chain linkages to top-level predators in Monterey Bay can be very short, incorporating large herbivores such as krill, anchovies and sardines as key intermediates (Ryther 1969). These planktivores thus represent a direct mechanism for the potentially rapid transfer of phycotoxins from toxic phytoplankton to higher-level consumers.

Recent events in Monterey Bay have demonstrated the transfer of the neurotoxin domoic acid (DA) from 
toxigenic species of the diatom Pseudo-nitzschia to sea lions and seabirds. The first major event occurred in 1991, when more than 200 brown pelicans and Brandt's cormorants were found dead on the beaches of Monterey Bay (Fritz et al. 1992, Work et al. 1993). Similarly, Monterey Bay was the site of another major DA poisoning incident in 1998, when sea lions were observed dying on the beaches suffering from neurological symptoms (Lefebvre et al. 1999, Scholin et al. 2000). In all DA poisoning events in this region, Pseudo-nitzschia australis was determined to be the primary source of the toxin, and filter-feeding anchovies Engraulis mordax the apparent vector. Anchovies are not the only potential filter-feeding vectors of DA in the Monterey Bay system. For example, zooplankton are generally key consumers of phytoplankton. Nonetheless, while the link between zooplankton and toxic dinoflagellates has been confirmed (e.g. White 1981, Huntley et al. 1986, Ives 1987, McClatchie 1988, Uye \& Takamatsu 1990, Turriff et al. 1995, Bagoien et al. 1996, Teegarden \& Cembella 1996, Shaw et al. 1997, Turner \& Tester 1997, Tester et al. 2000, Turner et al. 2000), there has been less attention focused on toxin transfer between toxic diatoms and zooplankton grazers (Windust 1992, Tester et al. 2001, Lincoln et al. 2001).

Euphausiids (krill) are important members of the zooplankton grazer community in the world's oceans. As filter feeders, they directly link the base of the food chain to higher trophic levels. They can be consumed by large predators because of their relatively large size. This intermediary position in the pelagic food chain gives them a potentially critical role in toxin transfer. Euphausia pacifica and Thysanoessa spinifera are the most abundant euphausiids in the California Current system and are important indicators of oceanic and neritic water masses in the North Pacific Ocean, respectively (Ponomareva 1966, Schoenherr 1991). They are a common prey for many marine organisms ranging from fish to whales. Pelagic fishes such as Pacific herring, salmon and the Pacific hake (Yamamura et al. 1998), and seabirds such as Cassin's auklet and ashy storm petrel (Ainley et al. 1996) can feed heavily on krill in Monterey Bay. In addition to pelagic predators, demersal fish such as Pacific cod and rockfish feed directly on E. pacifica, which is found normally at greater depths during the day (Chess et al. 1988). Because krill can be found both near the surface and at depth, they can potentially introduce DA into both shallow and deep-dwelling predators. Additionally, krill fecal pellets sink at high rates (Komar et al. 1981), and could rapidly convey toxin-containing material to deep water and the benthos.

To better evaluate and understand the role of krill as a DA vector, we collected krill and water samples in
Monterey Bay throughout 2000. Additionally, we measured DA in krill and examined their digestive tract for toxic Pseudo-nitzschia species. Our results present clear evidence of the role of krill as a potential vector for the neurotoxin DA.

\section{MATERIALS AND METHODS}

Sample collection. Samples of the euphausiid Euphausia pacifica were collected opportunistically between March and August 2000 offshore of Monterey Bay, CA, USA, using $0.7 \mathrm{~m}$ BONGO nets fitted with $333 \mu \mathrm{m}$ mesh (Ocean Instruments). Samples were frozen immediately after collection, transferred to the UCSC laboratory packed on ice, and stored at $-20^{\circ} \mathrm{C}$ until analyzed for the presence of toxic Pseudonitzschia spp. in gut contents by scanning electron microscopy (SEM) and for the presence of DA by receptor binding assay. For DA analyses, samples were split and sent via overnight carrier on dry ice to the NOAA/NOS Charleston Laboratory. Water samples were also obtained to identify toxic Pseudonitzschia spp. co-occurring with krill, as well as to determine their cell numbers and cellular DA toxicity. Approximately $15 \mathrm{ml}$ aliquots of water were preserved in $10 \%$ Lugol's $\left(10 \% \mathrm{KI}, 5 \% \mathrm{I}_{2}\right.$ and $10 \%$ glacial acetic acid in $100 \mathrm{ml}$ deionized water) for identification of toxic Pseudo-nitzschia species present and confirmation by SEM. Another 15 to $30 \mathrm{ml}$ of water was collected for cell enumeration using rRNA probes. For cellular DA determinations, samples of $500 \mathrm{ml}$ water were filtered through $25 \mathrm{~mm}$ Whatman GF/F filters, immediately frozen, transferred to the UCSC laboratory packed on ice, and stored at $-80^{\circ} \mathrm{C}$ until analysis. A summary of both krill and water samples is given in Fig. 1 with location and collection dates plotted on a map of Monterey Bay.

Krill preparation for DA toxin analysis. Homogenization and extraction: Whole krill were used in the extraction process, because predators consume the entire organism. A minimum of 25 individual 15 to $28 \mathrm{~mm}$ specimens (equiv. to $2 \mathrm{~g}$ wet $\mathrm{wt}$ ) from each collection date was placed into a $50 \mathrm{ml}$ conical tube. An equal weight of Milli-Q water (Millipore) was added and blended using a polytron (PowerGen 700; Fisher Scientific) equipped with $10 \mathrm{~mm} \times 195 \mathrm{~mm}$ sawtooth generator probe at $10000 \mathrm{rpm}$ until the krill became a smooth homogenate (ca. $2 \mathrm{~min}$ ).

DA was extracted from krill according to the method of Quilliam et al. (1995) with modifications as described by Powell et al. (2002). Krill extracts were cleaned using a strong anion exchange (SAX)-solid phase extraction as described by Hatfield et al. (1994). 
DA extraction efficiency from krill: The DA extraction efficiency for krill was tested by performing spikerecovery experiments. Control krill, Thysanoessa spinifera, obtained from Monterey Bay during nonbloom periods, were used and verified by receptorbinding assay to contain $<0.01 \mu \mathrm{g}$ DA equiv. $\mathrm{g}^{-1}$ tissue following the protocol described above. Subsequently, individual krill were injected with a known amount of DACS-1C, a certified DA reference standard (Institute for Marine Biosciences, National Research Council of Canada, NS, Canada), into the ventral side of each krill abdomen with 4 replicate samples of 25 individuals each. An additional recovery test was performed by spiking 4 replicate krill homogenates with DACS-1C standard. Extracts were analyzed by receptor binding assay and percent recoveries determined.

DA toxin analysis of krill using receptor binding assay. Prior to testing on the assay, naturally occurring glutamate was removed from SAX-cleaned krill extracts by incubating $50 \mu \mathrm{l}$ of sample with $40 \mu \mathrm{l}$ citrate buffer (10 mM citrate, pH 5.0; 2 mM pyridoxal 5-phosphate; $200 \mathrm{mM} \mathrm{NaCl}$ ) and $10 \mu \mathrm{l}$ glutamate decarboxylase (100 units $\mathrm{ml}^{-1}$ in $10 \mathrm{mM}$ citrate, $\mathrm{pH}$ 5.0) for $30 \mathrm{~min}$ at $4^{\circ} \mathrm{C}$. Receptor assays were performed in 96-well microtiter filtration plates (Millipore) and employed a cloned rat GluR6 glutamate receptor expressed in SF9 insect cells using a bacculovirus expression system (Van Dolah et al. 1997). The endpoint of this competitive binding assay was determined by microplate scintillation counting (Microbeta 1450; Wallac). Additional details of the domoic acid receptor binding assay are provided in Lefebvre et al. (1999).

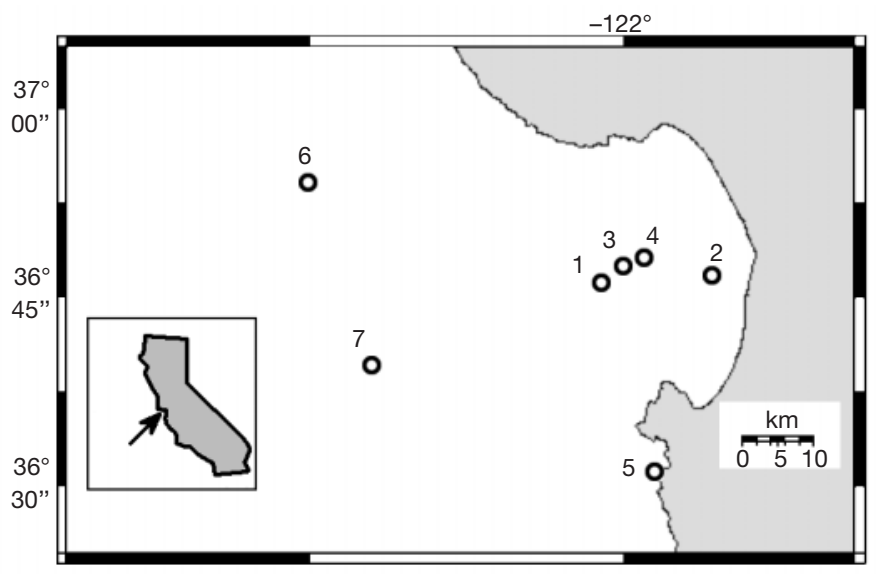

Fig. 1. Map of Monterey Bay, CA, USA, showing sites of krill and water sample collections. Positions of numbered study sites indicate collection dates (given as mm/dd/yy) and locations of krill and water samples: 1 (03/22/00, 122 $\left.{ }^{\circ} 02.18^{\prime} \mathrm{W}, 36^{\circ} 46.26^{\prime} \mathrm{N}\right)$, $2\left(05 / 15 / 00,121^{\circ} 51.69^{\prime} \mathrm{W}, 36^{\circ} 46.78^{\prime} \mathrm{N}\right), 3\left(07 / 03 / 00,122^{\circ} 00^{\prime} \mathrm{W}\right.$, $\left.36^{\circ} 47.79^{\prime} \mathrm{N}\right), \quad 4 \quad\left(08 / 07 / 00,121^{\circ} 58.37^{\prime} \mathrm{W}, 36^{\circ} 47.82^{\prime} \mathrm{N}\right), \quad 5$ $\left(08 / 24 / 00,121^{\circ} 57.4^{\prime} \mathrm{W}, 36^{\circ} 31.3^{\prime} \mathrm{N}\right), 6\left(08 / 27 / 00,122^{\circ} 30.25^{\prime} \mathrm{W}\right.$, $\left.36^{\circ} 53.72^{\prime} \mathrm{N}\right), 7\left(08 / 29 / 00,122^{\circ} 22.30^{\prime} \mathrm{W}, 36^{\circ} 39.81^{\prime} \mathrm{N}\right)$
LC-MS/MS for DA. Selected krill extracts were analyzed by liquid chromatography coupled with tandem mass spectrometric detection (LC-MS/MS) for the absolute confirmation of DA. Liquid chromatographic separation was performed on a Vydac 201TP52 $\mathrm{C}_{18}$ column (2.1 mm $\times 250 \mathrm{~mm}$; Separations Group) with an elution gradient of 1 to $95 \%$ aqueous $\mathrm{MeOH}$ in $0.1 \%$ trifluoroacetic acid (TFA) run over 35 min at a flow rate of $0.2 \mathrm{ml} \mathrm{min} \mathrm{m}^{-1}$. Following separation, the eluent was introduced into a PE SCIEX API-III triple quadrupole mass spectrometer (SCIEX Instruments) operating in positive ion mode and using compressed air as the nebulization gas. Confirmation of DA was by selective ion monitoring based on the MS/MS fragmentation pattern for this toxin given by Quilliam (1996), including the parent ion $(312 \mathrm{~m} / \mathrm{z})$ and 2 diagnostic fragment ions produced by collisionally induced dissociation (161 and $266 \mathrm{~m} / \mathrm{z}$ ).

DA toxin analysis of water samples. Cellular DA concentrations in microalgae were determined using the FMOC-HPLC method described by Pocklington et al. (1990), which involves pre-column derivatization of DA in cell extracts with 9-fluorenylmethylchloroformate (FMOC) reagent to form the fluorescent FMOCderivative of DA. Prior to analysis, particulate samples collected on Whatman GF/F filters were extracted in $2.5 \mathrm{ml} 10 \%$ aqueous $\mathrm{MeOH}$. For derivatization, $200 \mu \mathrm{l}$ of extract were vortexed with $50 \mu \mathrm{l} 1 \mathrm{M}$ borate buffer (pH 6.2), $10 \mu \mathrm{l}$ dihydrokainic acid (DHKA) internal standard $\left(100 \mu \mathrm{g} \mathrm{ml}^{-1}\right.$ DHKA in $10 \%$ aqueous $\left.\mathrm{MeOH}\right)$ for $10 \mathrm{~s}$, and then $250 \mu \mathrm{FMOC}-\mathrm{Cl}$ reagent were added and vortexed again for $45 \mathrm{~s}$. Three ethyl acetate washes were performed and the aqueous layer was removed for HPLC analysis. A $5 \mu \mathrm{l}$ sample was injected into a Hewlett-Packard HP1090M HPLC equipped with an HP1046A fluorescence detector set for excitation at $264 \mathrm{~nm}$ and emission at $313 \mathrm{~nm}$ with a mobile phase flow rate of $0.2 \mathrm{ml} \mathrm{min}^{-1}$ comprised of $40 \%$ aqueous $\mathrm{MeCN}, 0.1 \% \mathrm{TFA}$. Isocratic separations were performed on a reverse phase $\mathrm{C}_{18}$ column $(2.1 \mathrm{~mm} \times$ $25 \mathrm{~mm}$, Vydac 201TP52; Separations Group) heated to $40^{\circ} \mathrm{C}$. A calibration curve of 5,10,25,50, 100 and $250 \mathrm{ng} \mathrm{ml}^{-1}$ in $10 \%$ aqueous $\mathrm{MeOH}$ was generated using the DACS-1C standard $\left(\mathrm{r}^{2}=0.99\right)$.

Toxic Pseudo-nitzschia cell counts. Water column abundance of toxic Pseudo-nitzschia australis and $P$. multiseries was determined using whole cell hybridization with species-specific large subunit (LSU) rRNA-targeted fluorescent probes (Miller \& Scholin 1996). Between 5 and $30 \mathrm{ml}$ aliquots of seawater were filtered onto $1.2 \mu \mathrm{m}$ isopore polycarbonate filters (Millipore) and preserved with a saline ethanol solution for at least $1 \mathrm{~h}$. After rinsing with hybridization buffer (5× SET $\left[\frac{1}{5}\right.$ dilution of $3.75 \mathrm{M} \mathrm{NaCl}, 25 \mathrm{mM}$ EDTA, $0.5 \mathrm{M}$ Tris $\mathrm{HCl}, \mathrm{pH} 7.8$ ], $0.1 \%$ [v/v] IGEPAL-CA630 
[Sigma], $25 \mu \mathrm{g} \mathrm{ml}^{-1}$ polyadenylic acid [Sigma]), each sample was incubated with species-specific probes for $P$. australis, $P$. multiseries, a positive eukaryote control probe and a negative control probe designed for the dinoflagellate Alexandrium tamarense. A third control consisted of a sample with no probe added. After $1 \mathrm{~h}$, filters were rinsed and placed on microscope slides. Intact cells that retained the fluorescein labeled probe were then counted on a Zeiss Standard 18 compound microscope, equipped with epifluorescence (microscope illuminator 100, Zeiss). The entire area of each filter was counted. Results are given in cells $\mathrm{l}^{-1}$.

Scanning electron microscopy. Scanning electron microscopy (SEM) was used to verify the species composition of Pseudo-nitzschia in krill digestive tracts and seawater using methods slightly modified from Miller \& Scholin (1998). The gut contents of Euphausia pacifica were dissected from specimens under a dissecting microscope, removed from the body, and gently discharged into scintillation vials. All the gut samples were preserved in 5\% buffered formalin solution until being processed for SEM.

Dissected krill gut contents and water samples $(10 \mathrm{ml})$ were concentrated onto $1.2 \mu \mathrm{m}$ pore size isopore polycarbonate membranes (Millipore). Salt was removed from samples by rinsing with DI water under low vacuum pressure (150 $\mathrm{mm} \mathrm{Hg}$ ). To remove organic material, saturated $\mathrm{KMnO}_{4}$ was added until the filters were covered and allowed to digest the samples for $15 \mathrm{~min}$ (krill gut contents) or $5 \mathrm{~min}$ (water). $12 \mathrm{~N} \mathrm{HCl}$ ( $3 \mathrm{ml}$ ) was then added to the water samples until the color became clear. Krill gut contents were held for $30 \mathrm{~min}$ in $3 \mathrm{ml}$ of $12 \mathrm{~N} \mathrm{HCl}$ to complete the oxidation process. Samples were then vacuumed gently and rinsed with DI water. This process was repeated 2 times, and filters removed from the filter tubes and fixed to aluminum stubs. Filters were air-dried in a dessicator for $24 \mathrm{~h}$ and then mounted onto SEM stubs with double-sided tape and sputter coated with gold palladium. All micrographs were taken with an ISI WB-6 electron microscope at $10 \mathrm{kV}$.

\section{RESULTS}

\section{Protocol development}

The extraction methods used for domoic acid (DA) detection in animals can be adjusted depending on the size and physical structure of the animal. Since krill is a new matrix for DA measurement, testing the efficiency of the toxin extraction protocol was essential before running any field samples. Therefore, we conducted a spike-recovery test on control krill, Thysanoessa spinifera, samples obtained from Monterey Bay during non-bloom periods, verified by receptor binding assay to contain $<0.01 \mu \mathrm{g}$ DA equiv. $\mathrm{g}^{-1}$ tissue. Samples of krill injected individually with a known amount of DA yielded a recovery of $98 \pm 7.8 \%$, while the addition of DA to previously homogenized animals gave a recovery of $99 \pm 10.4 \%$. Both treatments showed very high recovery for DA. Although differences between the 2 methods were not significant ( $p>$ $0.05, t$-test), injection of individual animals may better represent natural conditions.

\section{Field krill samples}

DA in krill Euphausia pacifica collected from Monterey Bay between March and August 2000 ranged from 0.1 to $44 \mu \mathrm{g}$ DA equiv. $\mathrm{g}^{-1}$ tissue, as determined by receptor binding assay. DA content of krill varied according to the abundance of toxic Pseudo-nitzschia species in the water (Table 1), as demonstrated by a highly significant, positive correlation between these 2

Table 1. Field measurements of domoic acid in krill ( $\mathrm{n}=28$ to $56, \mu \mathrm{g}$ DA equiv. $\mathrm{g}^{-1}$ tissue) determined by receptor binding assay. In addition, values as shown for the corresponding abundance of toxic Pseudo-nitzschia (cells $\mathrm{l}^{-1}$ ) obtained using species-specific LSU rRNA-targeted fluorescent probes and for DA concentration per cell (pg DA equiv. cell ${ }^{-1}$ ) determined by HPLCFMOC. Both krill and water samples were obtained from Monterey Bay, CA, between March and August 2000

\begin{tabular}{|c|c|c|c|}
\hline $\begin{array}{l}\text { Sample collection } \\
\text { dates (mm/dd/yy) }\end{array}$ & $\begin{array}{c}10^{5} \text { toxic } \text { Pseudo-nitzschia cells } 1^{-1} \\
(P . \text { australis }+P \text {. multiseries })\end{array}$ & $\begin{array}{c}\text { Cellular DA } \\
\text { (pg DA equiv. cell }{ }^{-1} \\
\text { Pseudo-nitzschia) }\end{array}$ & $\begin{array}{c}\text { DA in krill } \\
\text { ( } \mu g \text { DA equiv. } g^{-1} \\
\text { tissue) }\end{array}$ \\
\hline 03/22/00 & 0.68 & 3 & 0.27 \\
\hline 05/15/00 & 0 & 0 & $<\mathrm{LD}^{\mathrm{a}}$ \\
\hline 07/03/00 & 0 & 0 & $<\mathrm{LD}^{\mathrm{a}}$ \\
\hline 08/07/00 & 0.54 & 14 & 0.34 \\
\hline 08/24/00 & 10 & 24 & 44 \\
\hline 08/27/00 & 0.0046 & 11 & 0.10 \\
\hline 08/29/00 & 0.31 & 16 & 0.31 \\
\hline
\end{tabular}


variables $\left(\mathrm{p} \ll 0.01, \mathrm{r}^{2}=0.998\right.$, Pearson Product Moment Correlation). The highest DA concentration in krill of $44 \mu \mathrm{g}$ DA equiv. $\mathrm{g}^{-1}$ was obtained during the August 2000 bloom event when P. australis reached $10^{6}$ cells $\mathrm{l}^{-1}$. Confirmation of DA in this particular sample was obtained by tandem mass spectrometry, which identified the parent ion of DA $(312 \mathrm{~m} / \mathrm{z})$ as well as its 2 diagnostic daughter ions (161 and $266 \mathrm{~m} / \mathrm{z}$ ) (Fig. 2). In addition to this sample, all other krill samples yielding positive DA-like activity on the receptor binding assay (see Table 1) were later confirmed by mass spectrometry to contain DA.

SEM analysis demonstrated that stomach contents of Euphausia pacifica were dominated by toxic Pseudo-nitzschia spp. when their cell numbers exceeded $10^{5}$ cells $1^{-1}$, but in the presence of lower cell numbers, assemblages of diatom frustules were mixed. E. pacifica shown to contain the highest concentrations of DA were found to have digestive tract contents dominated by Pseudonitzschia australis, thus implicating this phytoplankter as the most likely source of the toxin (Fig. 3). In contrast, when DA in E. pacifica was found in the range of $0.3 \mu \mathrm{g}$ DA equiv. $\mathrm{g}^{-1}$ tissue, concentrations of toxic

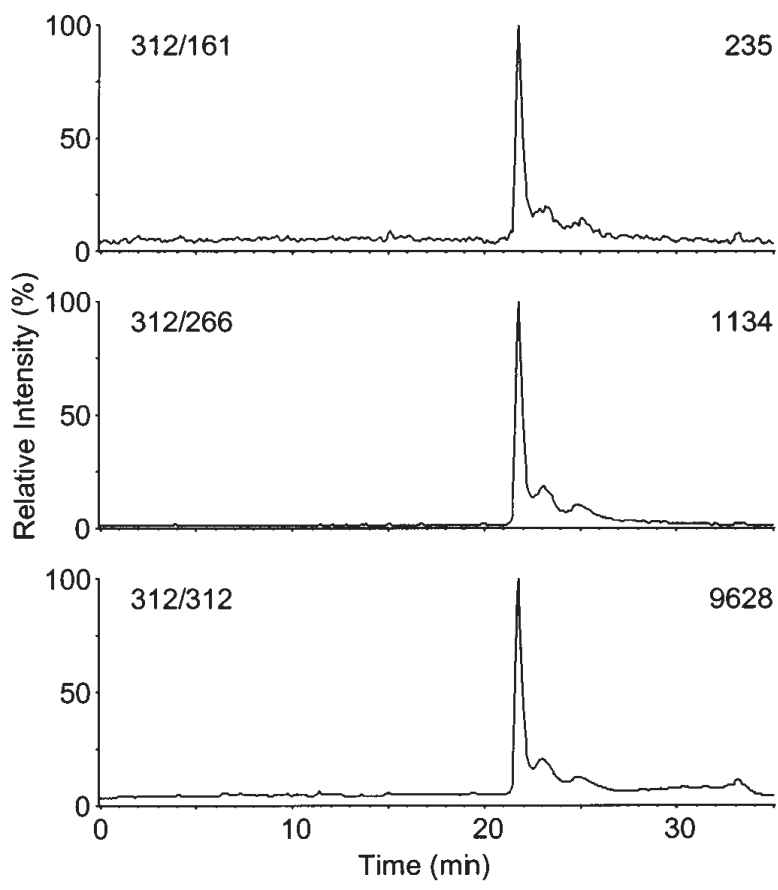

Fig. 2. LC-MS/MS chromatogram of krill extract taken from Monterey Bay, CA, on August 24, 2000, during Pseudonitzschia australis bloom event. The bottom chromatogram establishes the presence of the DA parent ion $(312 \mathrm{~m} / \mathrm{z})$ and the top panels show 2 diagnostic daughter ion fragments (161 and $266 \mathrm{~m} / \mathrm{z}$ ) according to Quilliam et al. (1996)

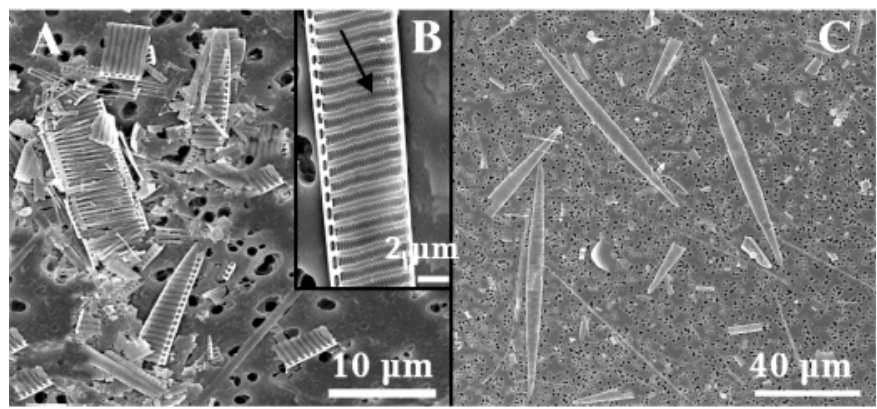

Fig. 3. (A) Scanning electron micrograph of DA-contaminated krill gut containing Pseudo-nitzschia australis frustules. (B) Higher magnification view of one of the frustules from (A) Arrow indicates the presence of 2 rows of large poroids within the striae. A central nodulus is absent. (C) Scanning electron micrograph of several $P$. australis frustules from water samples. Both krill and water samples were obtained during the August 2000 P. australis bloom event in Monterey Bay, CA

Pseudo-nitzschia spp. in the water were low and $P$. australis occurred in more mixed assemblages with small numbers of $P$. multiseries, another toxin-producing species as well as non-toxic diatom species, including $P$. pseudodelicatissima and P. pungens, Thalassiosira sp. cf. minima Gaarder, Skeletonema costatum, and Chaetoceros sp. Finally, no Pseudo-nitzschia frustules were observed in the stomachs of E. pacifica when toxic Pseudo-nitzschia were absent from the water, and correspondingly no DA was detected in either water or krill samples.

\section{DISCUSSION}

Food web contamination by DA may be widespread during blooms of toxic Pseudo-nitzschia species. After the first DA poisoning event in Monterey Bay, CA, in 1991, with northern anchovies Engraulis mordax suspected as the DA vector, researchers identified additional DA vectors on the US West Coast: mussels Mytilus californianus, razor clams Siliqua patula, dungeness crabs Cancer magister, and mole crabs Emerita analoga (Loscutoff 1992, Wohlgeschaffen et al. 1992, Langlois et al. 1993, Horner \& Postel 1993, Lund et al. 1997, Lefebvre et al. 1999). Very few studies, however, have focused on DA in zooplankton, specifically on copepods or euphausiids, and these 2 are the dominant phytophagous macrozooplankton groups in the Monterey Bay area. Both are efficient filter feeders of diatoms and comprise most of the zooplankton biomass in pelagic ecosystems, implicating them as potentially effective vectors for DA. Copepods have been found to accumulate DA in earlier studies (Windust 1992, Lincoln et al. 2001, Tester et al. 2001). The only previous 
report implicating krill as a DA vector is our own preliminary field observation showing that the digestive tract of krill contains both toxic and non-toxic Pseudonitzschia spp. during blooms of these diatoms (Bargu \& Silver in press). However, we could not perform toxin measurements on krill at the time due to technical difficulties. Therefore the present study is the first report confirming DA in krill during a bloom of toxin-producing diatom Pseudo-nitzschia.

DA concentrations in krill varied depending on the densities of toxic Pseudo-nitzschia cells in the water. Similar results were found for filter-feeding mussels (Silvert \& Rao 1991). The maximum level of DA in krill for this study was $44 \mu \mathrm{g}$ DA equiv. $\mathrm{g}^{-1}$ tissue $(3 \mu \mathrm{g}$ DA equiv. krill ${ }^{-1}$ ), somewhat higher than that found in dungeness crab (average $13 \mu \mathrm{g} \mathrm{DA} \mathrm{g}{ }^{-1}$ ) and mole crabs $\left(5 \mu \mathrm{g} \mathrm{DA} \mathrm{g}^{-1}\right.$ ) on the US West Coast (Wekell et al. 1994, Powell et al. 2002). Since the highest DA concentration measurement for krill exceeded the upper limit allowed for human consumption (i.e. $20 \mu \mathrm{g}$ DA $\mathrm{g}^{-1}$ for shellfish), toxin levels in krill may also represent a danger for marine mammals that feed on krill.

Since DA was measured in Euphausia pacifica only when toxic Pseudo-nitzschia spp. were present in the water column, we considered the possibility that krill do not retain and distribute the toxins in their tissues and organs but rather have toxin only pass in material within the gut. Because we did not separate the stomach contents from the body for toxin analyses, we could not test for the partitioning of DA into the various organs and tissues. Instead, we calculated whether it was possible that all of the measured DA in an individual krill came from $P$. australis material present in the krill's digestive tract. Considering the highest DA content per $P$. australis cell during the bloom was $24 \mathrm{pg} \mathrm{cell}^{-1}$ (see Table 1), the $44 \mu \mathrm{g}$ DA equiv. $\mathrm{g}^{-1}$ tissue means that a typical $70 \mathrm{mg} \mathrm{E}$. pacifica (wet wt) would contain approximately $10^{5}$ cells With cell concentrations of $10^{6} \mathrm{P}$. australis cells $\mathrm{l}^{-1}$ at the site with highest measured cell concentration (see Table 1), the DA measured in E. pacifica suggests that these animals were retaining cells removed from approximately $100 \mathrm{ml}$ of seawater. Since filtering rates of E. pacifica have been measured at $\sim 150 \mathrm{ml}$ $\mathrm{h}^{-1}$ (S.B. unpubl. data) and gut residency time measured at $\sim 2$ h (S.B. unpubl. data) such gut concentrations of $P$. australis in krill appear reasonable. The results of these calculations suggest that krill are retaining (i.e. assimilating) relatively little, if any, toxin from their food source. Thus, the high toxin levels found in individual specimens suggest that krill may serve as vectors only when toxic cells are in their digestive tract. Furthermore, the relationship between body burden of DA in field-collected krill and
DA in Pseudo-nitzschia available in the water (Table 1) corroborates this hypothesis. Nevertheless, controlled laboratory measurements of krill feeding and depuration are clearly needed for confirmation. For example, filtering rates may decline in the presence of toxic species, and the high toxin levels in krill could therefore represent retention from a previous exposure to the toxin.

The link from phytoplankton to euphausiids to blue whales is possibly the shortest food chain involving a large marine mammal. A single blue whale can consume up to 2 tons of krill each day (D. Croll pers. comm.), the equivalent of 20 million krill. Thus, krill could convey DA levels up to $62 \mathrm{~g}$ to a blue whale $\mathrm{d}^{-1}$, based on our maximum DA concentration measured in krill. This amount of DA would yield a dose of $0.62 \mathrm{mg} \mathrm{kg}^{-1}$ for an average blue whale weighing $100000 \mathrm{~kg}$, less than one-sixth of the $\mathrm{LD}_{50}$ reported for mice at $3.8 \mathrm{mg} \mathrm{kg}^{-1}$ (Iverson et al. 1989). Although this dosage is far less than what is considered to be lethal for mice, whales may have physiological factors that make them more susceptible to lower doses of DA. In 1987, 14 humpback whales died in Cape Cod, MA, USA, after consuming Atlantic mackerel containing saxitoxin (STX), a neurotoxin produced by dinoflagellates responsible for paralytic shellfish poisoning (Geraci et al. 1989). The calculated dosage of STX believed to be delivered to these humpbacks was $3.2 \mu \mathrm{g}$ per $\mathrm{kg}$ of body weight, several times less than what has been reported as the lethal oral dose for humans. Nonetheless, the authors suggested that the mammalian diving adaptation, which channels blood (and thus toxin) to the heart and brain and away from organs involved in detoxification (i.e. kidney and liver), rendered the whales more susceptible than usual to STX contained in the mackerel. A similar scenario is clearly possible with DA exposures in other cetaceans.

To date, assessment of the effect of toxic Pseudonitzschia blooms on higher-level consumers has depended on evidence from beach strandings. Undoubtedly, the consequences for consumers living offshore are difficult to measure, since considerable mortality may go unnoticed. Krill are common in both neritic and oceanic environments of Monterey Bay, and play a key role in the food chain as a link between phytoplankton and large predators such as baleen whales and seabirds. Our results demonstrate that during toxic Pseudo-nitzschia blooms, krill accumulate DA and thus may act as an effective vector for the direct transfer of DA to higher trophic levels. However, there is still much to learn about toxin transmission by krill, including whether DA affects krill behavior or mortality, before the role of krill is better understood in these events. 
Acknowledgements. We thank Dr. Baldo B. Marinovic, Dr. Christopher A. Scholin, Roman Marin and Dr. Francisco P. Chavez for their help on krill sample collections. We are grateful to Dr. Jonathan M. Krupp for his assistance with the scanning electron microscopy and Dr. Greta A. Fryxell for identifying Thalassiosira sp. cf. minima Gaarder. We also thank Dr. Don Croll for his valuable insights on whale feeding behavior. This study was supported by NOAA Award no. NA960P0476 (ECOHAB) to M.W.S. and by NOAA Coastal Ocean Program project no. ECO 99-184 to G.J.D. Funding was also provided by the Dr. Earl Myers and Ethel Myers Oceanographic and Marine Biology Trust to S.B.

Disclaimer: The National Ocean Service (NOS) does not approve, recommend, or endorse any product or material mentioned in this publication. No reference shall be made to NOS, or to this publication furnished by NOS, in any advertising or sales promotion which would indicate or imply that NOS approves, recommends, or endorses any product or material mentioned herein or which has as its purpose any intent to cause directly or indirectly the advertised product to be used or purchased because of NOS publication.

\section{LITERATURE CITED}

Ainley DG, Spear LB, Allen SG (1996) Variation in the diet of Cassin's auklet reveals spatial, seasonal and decadal occurrence patterns of euphausiids of California, USA. Mar Ecol Prog Ser 137(1):1-10

Bagoien E, Miranda A, Reguera B, Franco JM (1996) Effects of two paralytic shellfish toxin producing dinoflagellates on the pelagic harpacticoid copepod Euterpina acutifrons. Mar Biol 126:361-369

Bargu S, Silver MW (in press) First field evidence of krill grazing on the toxic diatom genus Pseudo-nitzschia in Monterey Bay. Calif Bull Mar Sci

Brown RGB, Barker SP, Gaskin DE (1979) Daytime surface swarming by Meganyctiphanes norvegica (M. Sars) (Crustacea: Euphausiacea) off Brier Island, Bay of Fundy. Can J Zool 57:2285-2291

Chess JR, Smith SE, Fischer PC (1988) Trophic relationships of the shortbelly rockfish, Sebastes jordanii, off Central California. Calif Coop Fish Invest Rep 29:129-136

Fritz L, Quilliam MA, Wright JLC, Beale AM, Work TM (1992) An outbreak of domoic acid poisoning attributed to the pennate diatom Pseudo-nitzschia australis. J Phycol 28: 439-442

Fryxell GA, Villac MC, Shapiro LP (1997) The occurrence of the toxic diatom genus Pseudo-nitzschia (Bacillariophyceae) on the West Coast of the USA, 1920-1996: a review. Phycologia 36(6):419-437

Geraci JR, Anderson DM, Timperi RJ, Aubin DJ, Early GA, Prescott JH, Mayo CA (1989) Humpback whales (Megaptera novaeangliae) fatally poisoned by dinoflagellate toxin. Can J Fish Aquat Sci 46:1895-1898

Hallegraeff GM (1993) A review of harmful algal blooms and their apparent global increase. Phycologia 32(2):79-99

Hatfield CL, Wekell JC, Gauglitz EJ Jr, Barnett HJ (1994) Salt clean-up procedure for the determination of domoic acid by HPLC. Nat Toxins 2:206-211

Holm-Hansen O, Huntley M (1984) Feeding requirements of krill in relation to food sources. J Crustac Biol 4:156-173

Horner RA, Postel JR (1993) Toxic diatoms in western Washington waters (U.S. West Coast). Hydrobiologia 269/270: 197-205

Huntley M, Sykes P, Rohan S, Marin V (1986) Chemicallymediated rejection of dinoflagellate prey by the copepods
Calanus pacificus and Paracalanus parvus: mechanism occurrence and significance. Mar Ecol Prog Ser 28:105-120 Iverson F, Truelove J, Nera E, Tryphonas L, Campbell J, Lok E (1989) Domoic acid poisoning and mussel intoxication: preliminary investigations into the response of mice and rats to toxic mussel extracts. Food Chem Toxicol 27:377-384

Ives JD (1987) Possible mechanisms underlying copepod grazing responses to levels of toxicity in red tide dinoflagellates. J Exp Mar Biol Ecol 112:131-145

Komar PD, Morse AP, Small LF, Fowler SW (1981) An analysis of sinking rates of natural copepod and euphausiid fecal pellets. Limnol Oceanogr 26:172-180

Langlois GW, Kizer KW, Hansgen R, Howell R, Loscutoff S (1993) Preliminary results of the California phytoplankton monitoring program. In: Abstracts - 6th Int Conf Toxic Marine Phytoplankton, Nantes, France, October 18-22, p 118

Lefebvre KA, Powell CL, Busman M, Doucette GJ and 7 others (1999) Detection of domoic acid in northern anchovies and California sea lions associated with an unusual mortality event. Nat Toxins 7:85-92

Lincoln JA, Turner JT, Bates SS, Léger C, Gauthier DA (2001) Feeding, egg production, and egg hatching success of the copepods Acartia tonsa and Temora longicornis on diets of the toxic diatom Pseudo-nitzschia multiseries and the non-toxic diatom Pseudo-nitzschia pungens. Hydrobiologia 453/454:107-120

Loscutoff S (1992) The West Coast experience-overview. In: Domoic Acid Workshop, San Pedro, California, February 6-8. Proc-US Food and Drug Administration, Pacific Region, California

Lund JK, Barnett HJ, Hatfield CL, Gauglitz Jr EJ, Wekell JC, Rasco B (1997) Domoic acid uptake and depuration in dungeness crab (Cancer magister Dana 1852). J Shellfish Res 16(1):225-231

McClatchie S (1988) Functional response of the euphausiid Thysanoessa raschii grazing on small diatoms and toxic dinoflagellates. J Mar Res 46:631-646

Miller PE, Scholin CA (1996) Identification of cultured Pseudo-nitzschia (Bacillariphyceae) using species-specific LSU rRNA-targeted fluorescent probes. J Phycol 32: 646-655

Miller P, Scholin CA (1998) Identification and enumeration of cultured Pseudo-nitzschia using species-specific LSU rRNA-targeted fluorescent probes and filter based whole cell hybridization. J Phycol 34:371-382

Morejohn GV, Harvey JT, Krasnow LT (1978) The importance of Loligo opalescens in the food web of marine vertebrates in Monterey Bay, California. Calif Fish Game 169:67-97

Nemoto T (1971/1972) History of research into the food and feeding of euphausiids. Proc R Soc Lond Ser B Biol Sci 73: 260-265

Opalinski KW, Maciejewska K, Georgieva LV (1997) Notes on food selection in the Antarctic krill Euphausia superba. Polar Biol 17:350-357

Pocklington R, Milley JE, Bates SS, Bird CJ, de Freitas ASW, Quilliam MA (1990) Trace determination of domoic acid in seawater and phytoplankton by high-performance liquid chromatography of the fluorenylmethoxycarbonyl (FMOC) derivative. Int J Environ Anal Chem 38:351-368

Ponomareva LA (1966) Euphausiids of the North Pacific, their distribution and ecology. Doklady Akad Nauk SSSR. Israel Program for Scientific Translation, Jerusalem, p 1-142

Powell CL, Ferdin ME, Busman M, Kvitek RG, Doucette GJ (2002) Development of a protocol for determination of domoic acid in sand crabs (Emerita analoga): a possible new indicator species. Toxicon 40:481-488 
Price HJ, Boyd KR, Boyd CM (1988) Omnivorous behavior of the Antarctic krill Euphausia superba. Mar Biol 97:67-77

Quilliam MA (1996) Liquid Chromatography-mass spectrometry of seafood toxins. J Chromatogr Library 59:415-444

Quilliam MA, Xie M, Harastaff WR (1995) A rapid extraction and clean-up procedure for the liquid chromatographic determination of domoic acid in unsalted seafood. AOAC Int J 78:543-554

Ryther JG (1969) Photosynthesis and fish production in the sea. Science 901:72-76

Schoenherr JR (1991) Blue whales feeding on high concentrations of euphausiids around Monterey Submarine Canyon. Can J Zool 69:583-594

Scholin CA et al. (2000) Mortality of sea lions along the central California coast linked to a toxic diatom bloom. Nature 403:80-84

Shaw BA, Andersen RJ, Harrison PJ (1997) Feeding deterrent and toxicity effects of apo-fucoxanthinoids and phycotoxins on a marine copepod (Tigriopus californicus). Mar Biol 128:273-280

Silvert W, Subba Rao DV (1991) Dynamic model of the flux of domoic acid, a neurotoxin, through a Mytilus edulis population. Can J Fish Aquat Sci 48:400-405

Smayda TS (1989) Primary production and the global epidemic of phytoplankton blooms in the sea: a linkage? In: Cosper EM, Briceli VM, Carpenter EJ (eds) Novel phytoplankton blooms: causes and impacts of recurrent brown tides and other unusual blooms. Springer, New York, p 449-483

Smith SE, Adams PB (1988) Daytime surface swarms of Thysanoessa spinifera (Euphausiacea) in the Gulf of the Farallones, California. Bull Mar Sci 42(1):76-84

Starr RM, Johnson KA, Laman EA, Cailliet GM (1998) Fishery resources of the Monterey Bay National Marine Sanctuary. California Sea Grant College System, University of California, La Jolla

Teegarden GJ, Cembella AD (1996) Grazing of toxic dinoflagellates, Alexandrium spp., by adult copepods of coastal Maine: implications for the fate of paralytic shellfish toxins in marine food webs. J Exp Mar Biol Ecol 196:145-176

Tester PA, Turner JT, Shea D (2000) Vectorial transport of toxins from the dinoflagellate Gymnodinium breve through copepods to fish. J Plankton Res 122(1):47-61

Tester PA, Pan Y, Doucette GJ (2001) Accumulation of domoic acid activity in copepeods. In: Hallegraeff GM, Blackburn SI, Bolch CJ, Lewis RJ (eds) Harmful algal blooms 2000. IOC-UNESCO, Paris

Turner JT, Tester PA (1997) Toxic marine phytoplankton,

Editorial responsibility: Michael Landry (Contributing Editor), Honolulu, Hawaii, USA zooplankton grazers, and pelagic food webs. Limnol Oceanogr 42:1203-1214

Turner JT, Doucette GJ, Powell CL, Kulis DM, Keafer BA, Anderson DM (2000) Accumulation of red tide toxins in larger size fractions of zooplankton assemblages from Massachusetts Bay, USA. Mar Ecol Prog Ser 203:95-107

Turriff N, Runge JA, Cembella AD (1995) Toxin accumulation and feeding behavior of the planktonic copepod Calanus finmarchicus to red-tide dinoflagellate Alexandrium excavatum. Mar Biol 123:55-64

Uye S, Takamatsu K (1990) Feeding interactions between planktonic copepods and red-tide flagellates from Japanese coastal waters. Mar Ecol Prog Ser 59:97-107

Van Dolah FM (2000) Marine algal toxins: origins, health effects, and their increased occurrence. Environ Health Perspectives 108(Suppl 1):133-141

Van Dolah FM, Leighfield TA, Haynes BL, Hampson DR, Ramsdell JS (1997) A microplate receptor assay for the amnesic shellfish poisoning toxin, domoic acid, utilizing a cloned glutamate receptor. Anal Biochem 245:102-105

Walz PM, Garrison DL, Graham WM, Cattey MA, Tjeerdema RS, Silver MW (1994) Domoic acid-producing diatom blooms in Monterey Bay, California: 1991-1993. Nat Toxins 2:271-279

Wekell JC, Gauglitz EJ, Barnett HJ, Hatfi CL, Eklund M (1994) The occurrence of domoic acid in razor clams (Siliqua patula), dungeness crab (Cancer magister), and anchovies (Engraulis mordax). J Shellfish Res 13(2):587-593

White AW (1981) Marine zooplankton can accumulate and retain dinoflagellate toxins and cause fish kills. Limnol Oceanogr 26:103-109

Windust A (1992) The responses of bacteria, microalgae and zooplankton to the diatom, Nitzschia pungens f. multiseries and its toxic metabolite domoic acid. MS thesis, Dalhousie University, Dalhousie, New Brunswick

Wohlgeschaffen GD, Mann KM, Subba Rao DV, Pocklington $\mathrm{R}$ (1992) Dynamics of the phycotoxin domoic acid: accumulation and excretion in two commercially important bivalves. J Appl Phycol 4:297-310

Work TM, Beale AM, Fritz L, Quilliam MA, Silver MW, Buck K, Wright JLC (1993) Domoic acid intoxication of brown pelicans and cormorants in Santa Cruz, California. In: Smayda TJ, Shimizu Y (eds) Toxic phytoplankton blooms in the sea. Elsevier, Amsterdam, p 643-649

Yamamura O, Inada I, Shimazaki K (1998) Predation on Euphausia pacifica by demersal fishes: predation impact and influence of physical variability. Mar Biol 132(2): 195-208

Submitted: August 13, 2001; Accepted: January 10, 2002

Proofs received from author(s): July 9, 2002 